\title{
Fast plastic scintillator with the high light yield
}

\author{
P.N.Zhmurin, D.A.Eliseev, V.N.Lebedev, V.N.Pereymak, \\ O.V.Svidlo, E.S.Velmozhnaya
}

\author{
Institute for Scintillation Materials, STC "Institute for Single Crystals", \\ National Academy of Sciences of Ukraine, 60 Nauky Ave., 61001 Kharkiv, \\ Ukraine
}

\author{
Received April 28, 2016
}

\begin{abstract}
A fast plastic scintillator (PS) on combined base, consisting of 60 wt. $\%$ polystyrene and 40 wt. $\%$ N-tolylcarbazole, is presented. Relatively to known fast PS, in which luminescence quenching method is used to reduce the rise time, the new PS has both as the short scintillation flash rise time $(\sigma=167 \mathrm{ps})$, as the high light yield 11040 photon/MeV (79\% relatively to anthracene). Such unique combination of the parameters is reached by introduction, into the PS composition, N-tolylcarbazole - a dopant with the strong electron-donating properties and the low ionization potential.
\end{abstract}

Keywords: plastic scintillator, rise time, light yield.

\begin{abstract}
Представлен быстрый пластмассовый сцинтиллятор (ПС) на комбинированной основе, состоящей 60 мас.\% полистирола и 40 мас.\% $\mathrm{N}$-толилкарбазола. По сравнению с известными быстрыми ПС, в которых для уменьшения времени нарастания используются способы тушения люминесценции, новый ПС имеет как малое время нарастания сцинтилляционной вспышки ( $\sigma=167$ пс), так и большой световыход 11040 фотонов/МэВ (79 \% относительно антрацена). Такое уникальное сочетание параметров достигнуто благодаря введению в состав ПC NN-толилкарбазола - добавки с ярко выраженными электрон-донорными свойствами и низким потенциалом ионизации.
\end{abstract}

ІІвидкий пластмасовий сцинтилятор з високим світловіходом. Жлурін П.М., Єлісєєв Д.А., Лебедєв В.М., Перейлак В.М., Свідло О.В., Вельможна О.С.

Представлено швидкий пластмасовий сцинтилятор (ПС) на комбінованій основі, що складається з 60 мас.\% полістиролу і 40 мас.\% $\mathrm{N}$-толілкарбазолу. У порівнянні 3 відомими швидкими ПС, в яких для зменшення часу наростання використовуються способи гасіння люмінесценції, новий ПС має як малий час наростання сцинтиляційного спалаху ( $\sigma=167$ пс), так і високий світловий вихід 11040 фотонів/MеВ (79\% відносно антрацену). Таке унікальне поєднання параметрів досягнуто завдяки введенню до складу ПС $\mathrm{N}$-толілкарбазолу - добавки з яскраво вираженими електронодонорними властивостями і низьким потенціалом іонізації.

\section{Introduction}

In experimental nuclear and elementary particle physics, fast plastic scintillators (PS), which have the shorter scintillation flash rise time relatively to the general-purpose PS of type UPS-923A. This polystyrene based PS contains 2 wt. $\%$ para-terphenyl
(p-TP) and 0.1 wt. $\%$ 2,2'-(1,4-phenylene)bis(5-phenyl-1,3-oxazole) (POPOP) and has the scintillation flash rise time on amplitude level from 0.1 to $0.9 t_{\text {rise }}=1.1 \mathrm{~ns}$, and decay time $\sim 3 \mathrm{~ns}$ and light yield of $57 \%$ relatively to antracene [1,2].

Fast PS are obtained by acceleration of the emission process, what is reached either 
by increase of primary dye (acceptor) content or by add of special luminescence quenchers into the PS composition. In the first case, concentration quenching of activator excited states emission originates, in the second - partial radiationless deactivation of this states by the quenching dye molecules. The main drawback of these methods is significant decrease of the scintillation flash intensity, what decreases the temporal precision and complicates experimental technique. Thus, fast PS of mark EG-232 (another name NE111, BC422) [3, 4] on polyvinyltoluene base (PVT) with increased activator content $(5.0$ wt. $\%$ 2phenyl-5(4-biphenylyl)-1,3,4-oxadiazole (PBD)) has the scintillation flash rise time, in the amplitude range from 0.1 to 0.9 , of $0.35 \mathrm{~ns}$ and the decreased scintillation efficiency of $55 \%$ relatively to antracene, that is less than the general-purpose PS of type $\mathrm{BC}-408$ or EJ-200 $(\mathrm{SE}=67 \%$ relatively to antracene) [5-7].

The fast PS of mark EJ-232Q (BC422Q) additionally contents 0.5 wt. $\%$ benzophenone as a quencher [8,9], that allows to decrease the rise time to $0.11 \mathrm{~ns}$, but wherein the light yield decreases to $19 \%$ relatively to antracene and the PS material transparency sharply decreases [10].

In the work [11] the first method to improve the PS temporal properties without light yield loss is presented. This method is to accelerate the acceptor excited states formation process by increase of the charge carriers' mobility in the polymeric matrix, but not by shortening of the emission process by its quenching.

For realization of this method, the authors used the percolation theory, which is widely used for description of conductivity of disordered media. Respectively to this theory, medium becomes to be conductive, when the charge carriers' concentration exceeds the certain threshold value, which is called the percolation threshold [12]. Wherein, the charge donor concentration percolation threshold exceeds the value of several tens percent. As the charge donor, the authors introduced, into PS composition, up to $40 \mathrm{wt} \%$ triphenylamine (TPA), which contains nitrogen in the tertiary state, that makes it a substance with the strong electron-donating properties. Wherein, the polymeric matrix, modified with TPA, acquires the properties of p-type semiconductor [13-18]. At so high TPA content, the mobility of primary electron-hole pairs, created by an ionizing particle, sig-
Table 1. Solubility of carbazole derivatives in styrene and polystyrene

\begin{tabular}{|c|c|c|c||}
\hline \multirow{2}{*}{ Substances } & \multicolumn{3}{|c|}{ Solubility, $\omega($ wt. \%) } \\
\cline { 2 - 4 } & $\begin{array}{c}\text { Styrene, } \\
20^{\circ} \mathrm{C}\end{array}$ & $\begin{array}{c}\text { Styrene, } \\
70^{\circ} \mathrm{C}\end{array}$ & Polystyrene \\
\hline Phenylcarbazole & 8 & 40 & 35 \\
Tolylcarbazole & 10 & 50 & 45 \\
\hline
\end{tabular}

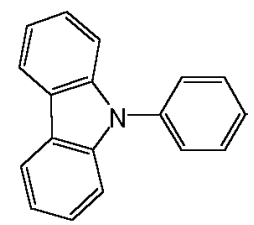

Phenylcarbazole

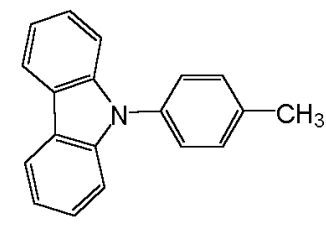

Tolylcarbazole
Fig. 1. Structural schemes of phenylcarbazole and tolylcarbazole.

nificantly increases, that leads to accelerated charge recombination, so to decrease of the scintillation flash rise time. The obtained PS on polystyrene base with 40 wt.\% TPA [11] has the scintillation pulse rise time of $0.5 \mathrm{~ns}$ (in the amplitude range from 0.1 to 0.9 ) and $15 \%$ higher scintillation efficiency relatively to the general purpose PS UPS-923A [19].

The aim of this work is further improvement in the properties of the fast PS on polystyrene base, modified by substances with the electron-donating properties.

\section{Experimental}

As substances with the electron-donating properties, which contain nitrogen in tertiary state, carbazole derivatives - phenylcarbazole and tolylcarbazole (9-p-tolyl-9Hcarbazole ( $p$-TCz)) (Table 1) were used in the present work.

As it can be seen in Table 1, phenylcarbazole and tolylcarbazole have solubility in polystyrene of 35 and 45 wt.\%, respectively. However, as it has been found in studies, the properties of PS with content of 35 wt. $\%$ phenylcarbazole are worse, than with 40 wt. $\%$ TPA. Therefore, further results will be discussed regarding preparing and properties of the PS with tolylcarbazole (Fig. 1).

Synthesis of 9-p-tolyl-9H-carbazole ( $p$-tolylcarbazole, $\mathrm{p}$-TCz) is was performed under according to the scheme, showed in Fig. 2.

$90 \mathrm{~g}$ (0.413 mole) iodotoluene, $69 \mathrm{~g}$ ( 0.413 mole) carbazole, $70 \mathrm{~g}(0.5$ mole $)$ potash, $5 \mathrm{~g}$ copper powder and $1 \mathrm{~g}$ phenan- 

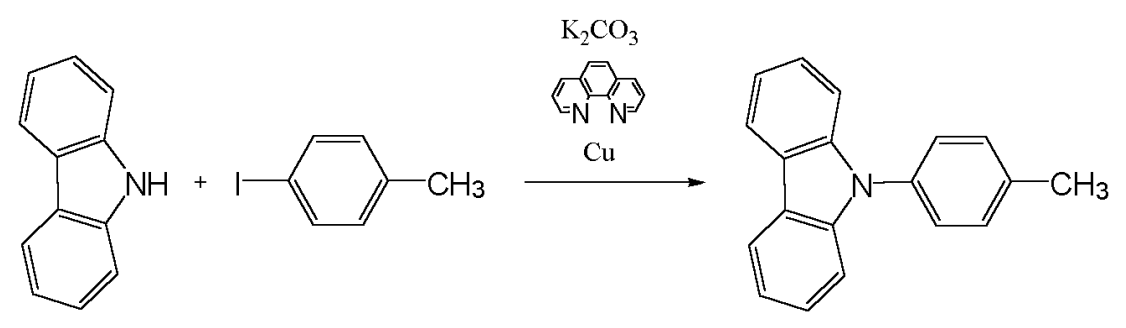

Fig. 2. Scheme of 9-p-tolyl-9H-carbazole synthesis.

throline were placed into a flask with the volume of $0.25 \mathrm{l}$. The reaction mixture was heated to $200^{\circ} \mathrm{C}$ and kept at this temperature for $20 \mathrm{~h}$. After cooling, the reaction mixture was placed into a glass with $500 \mathrm{ml}$ of hot water, thoroughly mixed, filtered and washed on a filter with hot water. Precipitate on the filter was pretty pressed, washed with some amount of cold hexane, and then was dried in air at the room temperature.

Purification was performed by double chromatography on aluminum oxide (eluents - cyclohexane and hexane) with following recrystallization from hexane. Output was $76 \mathrm{~g}$ colorless crystals, $T_{\text {melt }}=$ $85^{\circ} \mathrm{C}$.

In Fig. 3, excitation and luminescence spectra of 40 wt. $\%$ tolylcarbazole in polystyrene are presented. The sample thickness is of $3 \mathrm{~mm}$.

In Fig. 3 it is seen, tolylcarbazole is effectively excited through the polystyrene base, that confirms by existence of an excitation band in the range from 260 to $270 \mathrm{~ns}$, coinciding the absorption band of polystyrene. The luminescence band of the composition is located in the range of 240$390 \mathrm{~nm}$ and has the maximum at the wavelength of $360 \mathrm{~nm}$. This allows to use, as the activator (primary dye), a well-known scintillation dye 2,2'-(1,4-phenylene)bis-(5phenyl-1,3-oxazole) (POPOP), the absorption band of which has the maximum at the wavelength of $360 \mathrm{~nm}$ [20]. Taking into account these spectral data, the following composition of the new PS has been determined: 59 wt. $\%$ styrene, 40 wt. $\% \mathrm{~N}$-tolylcarbazole (TCz), and 1 wt. $\%$ POPOP. As it is seen in Table $1, \mathrm{~N}$-tolylcarbazole content is close to the maximum, and POPOP content is common for primary dopants and amounts of $1 \mathrm{wt} . \%$ [21].

The PS samples were obtained by the known method of thermal polymerization with the following mechanical tooling.

Into a heat-resistant glass ampoule of $18 \mathrm{~mm}$ in diameter $40 \mathrm{wt} . \%(64 \mathrm{~g})$ tolylcar-

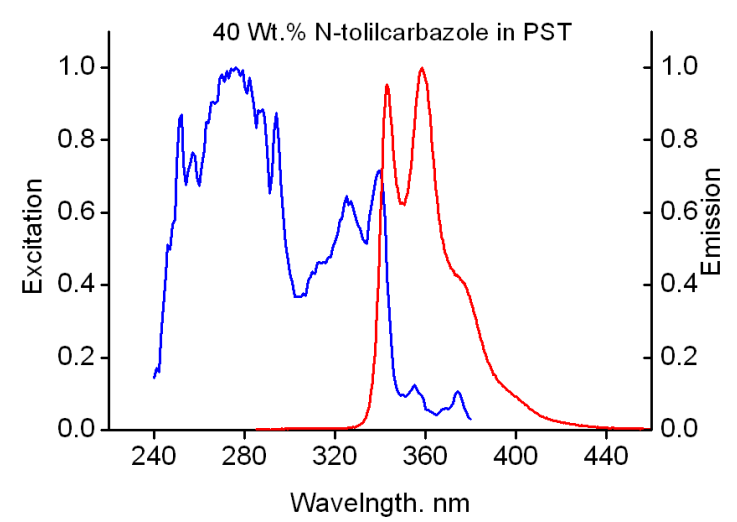

Fig. 3. Excitation and luminescence spectra of a 40 wt. $\%$ tolylcarbazole in polystyrene sample. The sample thickness is of $3 \mathrm{~mm}$.

bazole and 1 wt.\% (1.6 g) POPOP were put and styrene was added to reaching the general mass of $160 \mathrm{~g}$. For full dissolution of the dyes, the ampoule was heated to $78^{\circ} \mathrm{C}$ and saturated with argon for 6 min. Then this ampoule was sealed, placed into a thermostat and retained at the temperature of $155^{\circ} \mathrm{C}$ for $96 \mathrm{~h}$. Then the thermostat was cooled with the rate of $5{ }^{\circ} \mathrm{C} / \mathrm{h}$ to $40^{\circ} \mathrm{C}$, the ampoule was removed, cooled to the room temperature, and then a PS bar was obtained.

Prepared polished PS samples in the form of cylinders of $16 \mathrm{~mm}$ in diameter and $10 \mathrm{~mm}$ in thickness for light yield measurements, and the PS samples in the form of disks of $10 \mathrm{~mm}$ in diameter and $0.5 \mathrm{~mm}$ in thickness for temporal measurements were obtained by mechanical tooling.

For measurement of the PS samples light yield, spectrometric setup, designed in the CAMAC standard, was used. For registration of the scintillation flash from the PS, a photomultiplier tube Hamamatsu R1307 was used. The PMT anode signal was simultaneously fed to the leading edge discriminator (LED) input and through the delay line to charge-digital converter Lecroy 2249A (QDC). The generated pulse from the LED output with the duration of $200 \mathrm{~ns}$ was fed to QDC gate input and to controller 


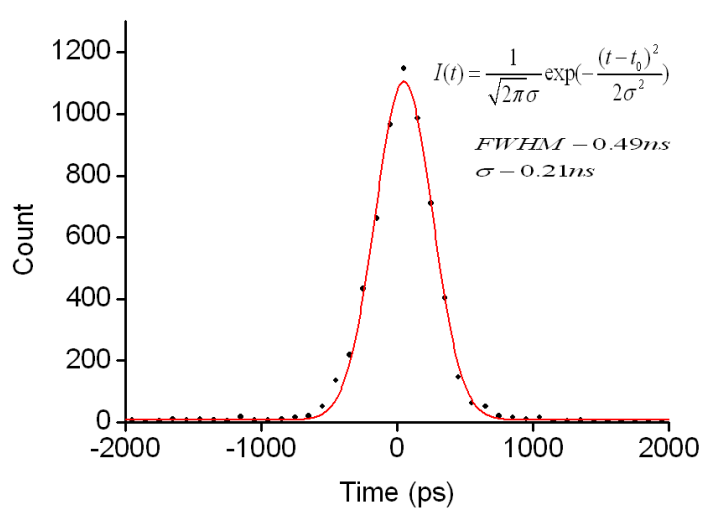

Fig. 4. Instrumental response spectrum (dots) and curve of experimental data fitting with the Gauss function (solid line). 1 channel $=100 \mathrm{ps}$.

input, which generates the signal to record the QDC code into IBM PC buffer through LPT port.

For the PS samples excitation, a collimated source $\mathrm{Bi}-207$ with electron energy $E_{e}=0.975 \mathrm{MeV}$. The scintillator was in optical contact with the PMT window. The refraction index of the immersion liquid was $n=1.5$.

The scintillation flash rise time was measured by the photon counting method by start-stop time-spectrometer with two fast PMT Hamamatsu R9800 (the rise time was of $0.9 \mathrm{~ns}$, the transit time spread was of $0.27 \mathrm{~ns})$. The collimated beam of beta-particles from the radioactive source Sr-90 passed through the thin studied PS sample into the quartz Cherenkov detector, the signal from which was registered by one of the PMT and formed the start pulse. The second PMT worked in the single-photon regime and registered photons from the studied PS sample, which had the shape of the polished disk $10 \mathrm{~mm}$ in diameter and $0.5 \mathrm{~mm}$ in thickness.

The start and stop signals from the PMT anodes were fed to the inputs of two-channel digital oscilloscope Rigol DS1302CA, which was connected to IBM PC with USBport. Ratio of the stop signals to the start signals during the measurement did not exceed $2 \%$.

Shapes of the start and stop signals in the digital form were recorded from the oscilloscope buffer to the computer memory. Then, the time interval between the start and stop pulses was found with the special program. Wherein constant time fraction discrimination was performed at fraction equal 0.5 .

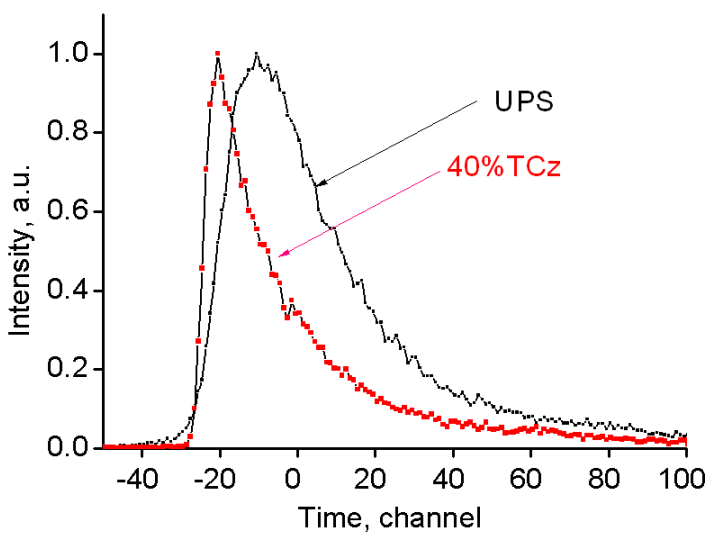

Fig. 5. Experimental data spectra of new fast PS with 40 wt. $\% \mathrm{TCz}$ and standard UPS923A. 1 channel $=0.1$ ns.

The instrument response resolution time was found from the experimental time spectrum, obtained by change of the PS sample to polymethylmethacrylate (PMMA) sample with the same dimensions. PMMA doesn't scintillate, but while passing of the fast electron, forms the short Cherenkov radiation pulse. The instrumental time spectrum, registered in such a way, is presented in Fig. 4.

As a result of the instrument response function (Fig. 4) fitting with the Gauss function, it is found, that the width at the half maximum of the instrument response function is $\mathrm{FWHM}=490 \mathrm{ps}, \quad \sigma=210 \mathrm{ps}$ and the rise time is $t_{0.1-0.9}=350$ ps. Therefore, the spectrometer allows to visually distinguish the time spectra with the rise time $t_{0.1-0.9}>350 \mathrm{ps}$ (without instrument resolution account).

\section{Results and discussion}

The experimental time spectra of the new fast PS with $40 \mathrm{wt} . \% \mathrm{TCz}$ and the standard PS UPS-923A are presented in Fig. 5.

The registered pulses front edge fitting (Fig. 5) by the piecewise linear interpolation method results the pulse rise time of $t_{0.1-0.9}=0.4 \mathrm{~ns}$ for the PS with $40 \mathrm{wt} . \%$ $\mathrm{TCz}$ and $t_{0.1-0.9}=1.1 \mathrm{~ns}$ for UPS-923A (Table 2).

The experimental spectrum fitting (Fig. 6) was performed by function

$$
I(t)=\int_{0}^{\infty} A \exp \left(\frac{-(t-\tau)^{2}}{2 \sigma^{2}}\right) \exp \left(-\frac{\tau}{\tau_{\text {decay }}}\right) d \tau,
$$

where $\sigma^{2}$ - the entire system pulse response dispersion, $\tau_{\text {decay }}-$ decay time of the excited state, results $\sigma=0.167 \mathrm{~ns}$, that 
Table 2. PS pulse rise time $\left(t_{0.1-0.9}, \sigma\right)$ and lifetime, determined by front edge interpolation and by fitting of experimental specters with function (1)

\begin{tabular}{||c|c|c|c|c|c||}
\hline \multirow{2}{*}{ PS } & \multirow{2}{*}{$\begin{array}{c}\text { Experimental. } \\
t_{0.1-0.9}, \mathrm{~ns}\end{array}$} & \multicolumn{3}{|c|}{ Deconvolution } & FWHM, ns \\
\cline { 3 - 6 } & & $t_{0.1-0.9}, \mathrm{~ns}$ & $\begin{array}{c}\text { sigmaBZZA }, \\
\mathrm{ns}\end{array}$ & $\tau, \mathrm{ns}$ & \\
\hline UPS-923A & 1.1 & 0.8 & 2.51 & 0.49 & \\
\hline $40 \% \mathrm{TPA}$ & 0.7 & 0.49 & 2.36 & 0.26 & \\
\hline $40 \% \mathrm{TCz}$ & 0.4 & 0.282 & 2.08 & 0.167 & \\
\hline
\end{tabular}

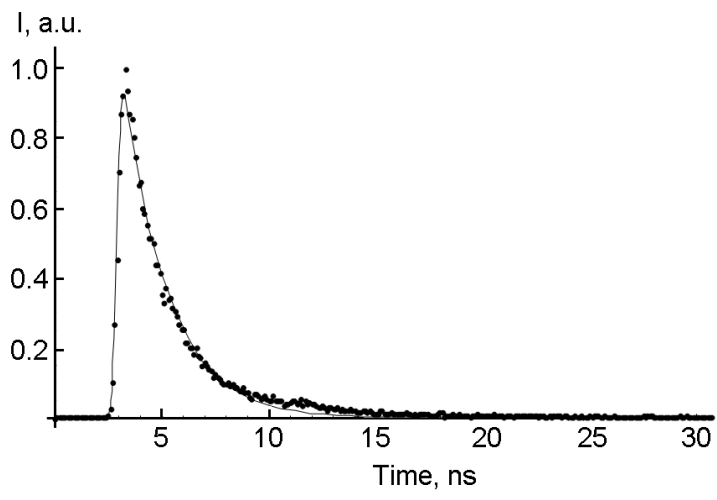

Fig. 6. Result of experimental spectrum (Fig. 5) fitting with function (1).

respects to the rise time $t_{0.1-0.9}=0.282 \mathrm{~ns}$, which is in 1.74 and 2.84 times faster, relatively to the value for the PS with TPA $\left(t_{0.1-0.9}=0.49 \mathrm{~ns}\right)$ and the standard UPS923A $\left(t_{0.1-0.9}=0.8 \mathrm{~ns}\right)$, respectively (Table 2). The decay time of the $\mathrm{PS}$ with $\mathrm{TCz}$ is shorter than the decay time of UPS-923A, it is associated with different POPOP content in these PS. UPS-923A contains 0.02 wt. \% POPOP, and in the PS with 40 wt. $\%$ TCz, concentration of POPOP is in 5 times more and amounts of $1.0 \mathrm{wt.} \%$.

In Fig. 7, the energy specters of electrons from radionuclide $\mathrm{Bi}-207$, registered with PS with 40 wt. $\% \quad \mathrm{TCz}$ and standard composition PS UPS-923A are presented. The light yield was determined by peak location of monoenergetic electrons with the energy value of $975 \mathrm{keV}$.

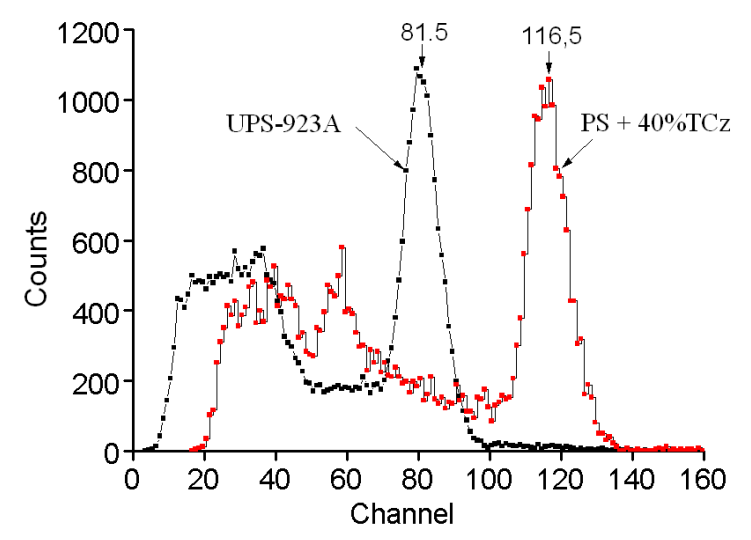

Fig. 7. Radionuclide Bi-207 electrons energetic spectra, registered with PS with 40 wt. $\% \mathrm{TCz}$ and standard composition PS UPS-923A. The arrows point to locations of electrons with energy of $975 \mathrm{keV}$.

It is seen in the presented in Fig. 7 energetic spectra, the light yield of the new fast PS with 40 wt. $\% \mathrm{TCz}$ exceeds the light yield of the standard PS of type UPS-923A on $38 \%$. In Table 3 it is seen, that the absolute light yields of the polystyrene base PS UPS-923A, the PS with 40 wt. $\%$ TPA and the new PS with 40 wt.\% $\mathrm{TCz}$ amount of 8000,9700 and 1140 photon/MeV, respectively.

Thus, the new PS with 40 wt. $\% \mathrm{TCz}$ is unique, because it has not only the short scintillation flash rise time, but also the record high light yield. Such PS light yield values could not be reached to this time both by combination of different activators

Table 3. Ionization potentials of tolylcarbazole (TCz), triphenylamine (TPA) and polystyrene (PST), and relative and absolute light yield of PS with their base

\begin{tabular}{|c|c|c|c||}
\hline \hline Substance & $\begin{array}{c}\text { Ionization } \\
\text { potential }\end{array}$ & Rel. light yield of PS & Abs. light yield of PS, photons $/ \mathrm{MeV}$ \\
\hline TCz & 5.6 & $1.38(40 \% \mathrm{TCz})$ & 11040 \\
\hline TPA & 6.4 & $1.22(40 \% \mathrm{TPA})$ & 9760 \\
\hline PST & 9.2 & $1.0(\mathrm{UPS}-923 \mathrm{~A})$ & 8000 \\
\hline
\end{tabular}


and shifters in polyvinyltoluene or polystyrene base PS compositions, and by choice of another bases.

How it was noticed, the short scintillation flash rise time in the new type PS is reached by introduction of substances with the strong electron-donating properties into the PS composition in big quantities (up to 40 wt. \%), that increases the charge carrier mobility in polymeric medium and leads to acceleration of scintillation process.

Wherein, the new type PS light yield increase is associated with the low ionization potential of the used electron-donating dopants. Indeed, how it is seen in Table 3, $\mathrm{TCz}$ has the lower ionization potential $(5.6 \mathrm{eV})$ relatively to triphenylamine (TPA) and polysterene (PST) (6.8 and $9.2 \mathrm{eV}$, respectively). This lowers the average ionization potential of the tolylcarbasole-polystyrene system and leads to increase of the general quantity of generated in the ionizing particle track electron-hole pairs and, consequently, to the PS light yield increase.

\section{Conclusions}

First $[19,22]$, on the combined base (polystyrene with 40 wt. $\%$ tolylcarbazole fast PS with the short rise time $\left(t_{0.1-0.9}=\right.$ $0.282 \mathrm{~ns}$ ) and the abnormally high for plastic scintillators light yield (11040 photons $/ \mathrm{MeV}$ or $79 \%$ relatively to antracene) was obtained. The high PS speed is provided by the strong electron-donating properties of $\mathrm{TCz}$, and the high light yield - by its low ionization potential. Wherein, the PS speed and the light yield grow with electron-donating dopant content increase.

As the primary luminescent dopant, in the presented PS, POPOP is used, the luminescence maximum of which is located at the wavelength of $418 \mathrm{~nm}$, that complies with the spectral sensitivity of the most of photomultiplier tubes (PMT).

\section{References}

1. A.Artikov, J.Budagov I. Chirikov-Zorin et al., Nucl.Instrum. Meth. Phys. Res., A 555, 125 (2005).

2. B.V. Griniov, V.G. Senchishin, Plastic scintillators, Kharkov, Acta, 32-44, 2003 (Russian)

3. http://www.eljentechnology.com/index.php/ products/plastic-scintillators/68-ej-232

4. Plastic Scintillators /BICRON Catalogue.

5. B.Bengtson, M.Moszynski, Nucl. Instr. Meth. Phys. Res., 155, 221 (1978).

6. B.Bengtson, M.Moszynski, Nucl. Instr. Meth. Phys. Res., 158, 1 (1979).

7 http://www.detectors.saint-gobain.com/plasticscintillator.aspx

8. http://www.eljentechnology.com/index.php/ products/plastic-scintillators

9. http://arxiv.org/ftp/arxiv/papers/1602/160 2.00944.pdf

10. R.Hoischen et al., Nucl. Inst. Meth. Phys. Res., A 654, 354 (2011).

11. P.N.Zhmurin, V.D.Titskaya, A.I.Bedrik et al., Functional Materials, 21, 195 (2014).

12. Monberg et al., Chem.Phys. Lett., 58, 492 (1978).

13. Physics of Organic Semiconductors, ed by W.Britting, WILEY-VCH, Weinheim (2005).

14. F.B.Koyuncua, S.Koyuncub, E.Ozdemira, Electrochim. Acta, 55, 4935 (2010).

15. Chia-Shing Wu, Yun Chen, J.Polymer Sci. Part A: Polymer Chem., 49, 3928 (2011).

16. H.Bassler, A.Kohler, Top Curr.Chem., 312, 1 (2012).

17. M.Redecker, H.Bassler, J.Phys.Chem.B, 101, 7398 (1997).

18. V.Mimaite, J.V.Grazulevicius, J.Ostrauskaite, V.Jankauskas, Dyes and Pigments, 95, 52 (2012).

19. Ukraine Patent 106857 (2014).

20. Isadore B. Berlman. Handbook of Fluorescence Spectra of Aromatic Molecules, Academic Press (1965).

21. J.B.Birks, The Theory and Practice of Scintillation Counting, Pergamon Press, London (1964).

22. Ukraine Patent 111126 (2016). 